\title{
Study of whole effluent acute toxicity test (Daphnia magna) as an evaluation of Ministry of Environment and Forestry Decree No. 3 In 2014 concerning industrial performance rank in environmental management
}

\author{
Neng Rohmah ${ }^{1}$, Dwina Roosmini ${ }^{2}$, and Mochamad Adi Septiono ${ }^{2}$ \\ ${ }^{1}$ Program Studi Teknik Lingkungan, Fakultas Teknik Sipil dan Lingkungan, Institut Teknologi Bandung, Jl Ganesha 10 Bandung \\ 40132 \\ ${ }^{2}$ Program Studi Teknik Lingkungan, Fakultas Teknik Sipil dan Lingkungan, Institut Teknologi Bandung, Jl Ganesha 10 \\ Bandung 40132
}

\begin{abstract}
Only $15 \%$ of the industries in Citarum Watershed, specifically in Bandung Regency, West Bandung Regency, Sumedang Regency, Bandung City and Cimahi City, are registered as PROPER industries. They must comply to indicators as set in the Minister of Environment and Forestry Decree No. 3 In 2014 concerning Industrial Performance Rank in Environmental Management, as a requirement to apply for PROPER. Wastewater treatment and management, referencing to Minister of Environment and Forestry Decree No. 5 In 2014 concerning Wastewater Effluent Standards, must be performed to be registered as PROPER industries. Conducting only physical-chemical parameter monitoring of wastewater is insufficient to determine the safety of wastewater discharged into the river, therefore additional toxicity tests involving bioindicator are required to determine acute toxicity characteristic of wastewater. The acute toxicity test quantifies $\mathrm{LC}_{50}$ value based on death response of bioindicators from certain dosage. Daphnia magna was used as bioindicator in the toxicity test and probit software for analysis. In 2015-2016, the number of industries that discharged wastewater exceeding the standard was found greater in non-PROPER industries than in PROPER industries. Based on the toxicity level, both PROPER and non-PROPER industries have toxic properties, however PROPER industries of 2015-2016 is more toxic with LC50 $0_{96}$ value reaching $2.79 \%$.
\end{abstract}

\section{Introduction}

PROPER (Program Penilaian Peringkat Kinerja Perusahaan/Assessment of Industrial Performance Rank Program) as industrial rank incentive of environmental aspect is one of efforts implemented by Indonesian Ministry of Environment and Forestry (MoEF) to pursue compliance of environmental management regulations. Registered PROPER industries in Upper Citarum watershed, specifically Bandung Regency; West Bandung; Sumedang Regency; Bandung City and Cimahi City, amount to only $15 \%$ of all industries around those locations (BPLHD West Java, 2015). PROPER industry participants must comply to certain parameters in Minister of Environment and Forestry Decree No. 3 In 2014 (PermenLKH No. 3/2014) to be registered. In regard to wastewater, there are further tests to be conducted and effluent standards to be complied, according to Minister of Environmental and Forestry Decree No. 5 In 2014 (PermenLKH No. 5/2014) concerning wastewater effluent standard, including physical, chemical and biological parameters.
Wastewater quality measurements in physical parameters have burden of solid dimensions, while chemical parameters require another chemical addition. Therefore, further biological tests exposing certain dosage on bioindicators is needed to determine toxicity level of discharged wastewater.

Physical and chemical parameter assessment alone would be insufficient in pointing out pollution impacts on aquatic organisms (Ningrum, 2012). Government regulations obligates to figure wastewater acute toxicity through death responses measurement of test animals from different dosage of wastewater. Concentration that causes $50 \%$ of bioindicator death response is used to estimate $\mathrm{LC}_{50}$ value in a period of observation time, according to Government Regulation No. 18 In 1999 (PP No. 18/1999). Acute and chronic toxicity is determined through toxicity tests (William and Burson, 1995). In this research, Daphnia magna is used as bioindicator to analyze acute toxicity, then using probit software in analysis.

\footnotetext{
Corresponding author: ${ }^{1} \mathrm{ftslnengrohmah@gmail.com,}{ }^{2}$ dwinaroosmini@yahoo.com, ${ }^{3}$ tioseptiono@gmail.com
} 


\section{Methodology}

Whole Effluent Toxicity (WET) tests was conducted with grab samples from registered PROPER and nonPROPER industries of 2015-2016 in Upper Citarum watershed, in Laboratory of Industrial Hygiene of Environmental Engineering ITB. Measurements of environmental parameters, namely $\mathrm{pH}$, dissolved oxygen, conductivity and temperature, were conducted. Names and classification/type of industry samples is shown in Figure 1. Two liters of wastewater samples was preserved at $4^{\circ} \mathrm{C}$ without additional preservatives, to prevent chemical transformation and microorganism degradation.

In these toxicity tests, Daphnia magna was used as bioindicator due to its simple method of cultivation in the lab and its important role in the food chain and sensitivity to various pollutants (Mark, 1997). WET Tests include 7 days of cultivation phase using bottled water instead of tap water to avoid chlorine contamination, which poisons Daphnia magna (US.EPA, 2002). During this process bioindicators were fed with yeast powder and sanitized properly.

WET test was conducted with variation of wastewater concentration, with each combination tripled and in static non-renewal, in which test organisms are exposed to a fresh solution of the same concentration of sample, either by transferring the test organisms from one test chamber to another, or by replacing all or a portion of solution in the test chambers (USEPA, 2002).

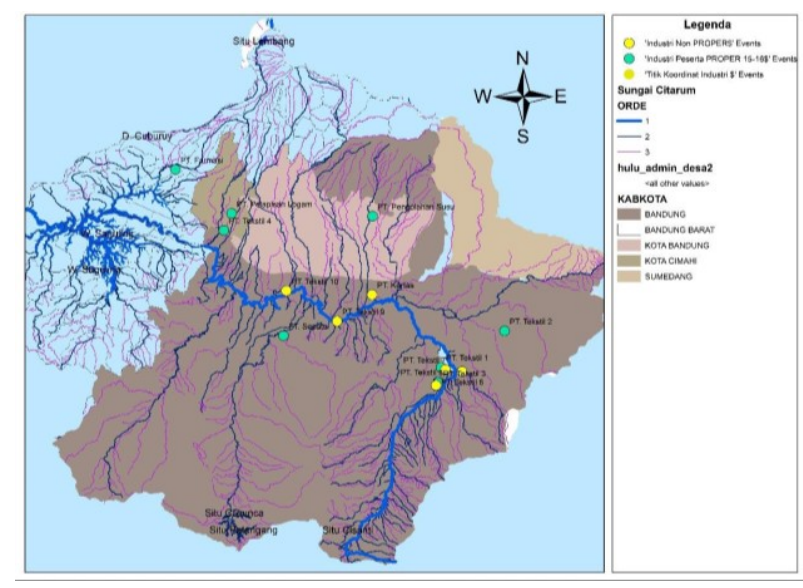

Figure 1 Location study

There are two stages in this method, namely range finding test and definitive test. Range finding test exposes test animal for 48 hours to the samples. Definitive test requires 96 hours in total, with number of death responses and environmental parameters need to be observed at each concentration every 24 hours. Standard measurement method of physical and chemical properties of the waste is shown in Table 1. In addition to those two stages of the test, samples underwent references toxicant test, which aims to determine level of sensitivity and health of test organisms over time. Mount, et al (1997) suggested that $\mathrm{LC}_{50}$ reference value of a toxicity test is $4.7 \mathrm{~g} / \mathrm{L}$, which means the WET tests are adequate to be conducted if the actual $\mathrm{LC}_{50}$ value of this test are close to the reference value.

Table 1 Characteristics parameter measurement method of physical-chemical

\begin{tabular}{|c|c|c|}
\hline Parameter & $\begin{array}{c}\text { Measurement } \\
\text { Method }\end{array}$ & $\begin{array}{c}\text { Standard of } \\
\text { Measurement }\end{array}$ \\
\hline $\mathrm{pH}$ & pH meter & SNI 06-6989.2-2009 \\
\hline Phosphate & Spectrophotometer & SNI 6989.76-2009 \\
\hline COD & Closed Reflux & SNI 6989.2-2009 \\
\hline Hardness & $\begin{array}{c}\text { Complexometry - } \\
\text { EDTA }\end{array}$ & SNI 06-6989.12-2004 \\
\hline Alkalinity & $\begin{array}{c}\text { Acid-Base } \\
\text { Titration }\end{array}$ & SNI 06-2420-1991 \\
\hline Ammonium & Spectrophotometer & SNI 19-6603-2001 \\
\hline TSS & Gravimetry & SNI 06-6989.3-2004 \\
\hline Conductivity & Conductivity meter & \\
\hline Temperature & Thermometer & \\
\hline DO & DO meter & \\
\hline Phenol & Spectrophotometer & SNI 06-6989.21-2004 \\
\hline TDS & Gravimetry & SNI 06-6989.3-2004 \\
\hline
\end{tabular}

In the range finding test, wastewater concentrations are shown in Table 2, which involved $40 \mathrm{~mL}$ of wastewater sample and six (6) Daphnia magna in each test chamber. Range finding test resulted in minimum and maximum concentration, which later were used in the definitive test. New set of concentration in the definitive test was measured using Equation 1. By multiplying $\mathrm{R}$ value to the smallest range, new concentration was able to be determined for definitive test.

Table 2 Variation of concentration in range finding test

\begin{tabular}{|c|c|c|c|}
\hline No. & $\begin{array}{c}\text { Waste Concentration } \\
(\mathbf{\%})\end{array}$ & $\begin{array}{c}\text { Wastewater } \\
(\mathbf{m L})\end{array}$ & $\begin{array}{c}\text { Dilution } \\
\text { Water } \\
(\mathbf{m L})\end{array}$ \\
\hline 1 & 6,25 & 2,5 & 37,5 \\
\hline 2 & 12,5 & 5 & 35 \\
\hline 3 & 25 & 10 & 30 \\
\hline 4 & 50 & 20 & 20 \\
\hline 5 & 100 & 40 & 0 \\
\hline
\end{tabular}

$$
r=\left(\frac{a}{b}\right)^{\frac{1}{n-1}}
$$

Description: $\quad r=$ constant

$\mathrm{a}=$ the highest concentration with mortality of $50 \%$

$\mathrm{b}=$ the lowest concentrations with mortality below $50 \%$

$\mathrm{n}=$ number of concentrations

\section{Result and Discussion}

\subsection{Participant of PROPER 2014-2015}

PermenLHK No. 3/2014 states PROPER is an evaluation of compliance and performance beyond compliance of industries or any activity in regards of pollution control, environmental impact assessments, and/or hazardous waste management. PROPER rates these performances into color-rated ranks namely black, as the least 
preferred, red, blue, green, and gold, as the most preferred.

PROPER industry ranks in this study area are shown in Figure 2. There had been 51 industries participated in PROPER in 2014 and 50 industries in the following year. There was 34 blue-ranked PROPER industries, then in 2015 the number increased to 37 . However, there had been declining numbers in green and gold ranks PROPER industries.

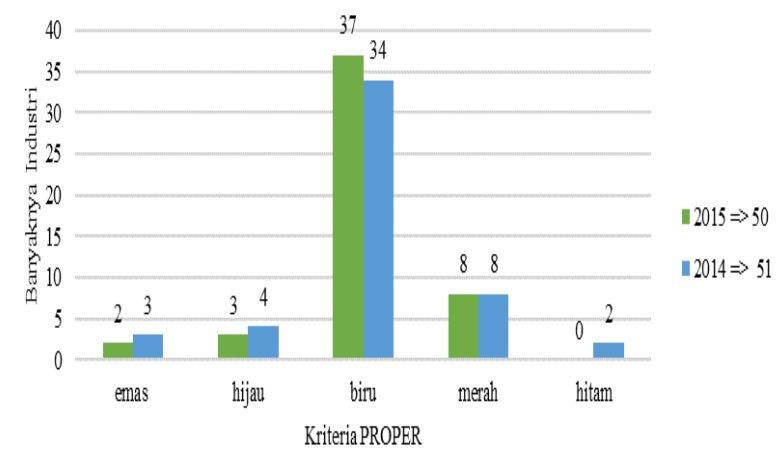

Figure 2 The Value PROPER In Citarum Hulu

Figure 3 shows PROPER industries based on their ranks around Upper Citarum area. Textile industries have the most blue-ranked industries, reaching to 10 , while red-ranked were hotels with 4 hotels.

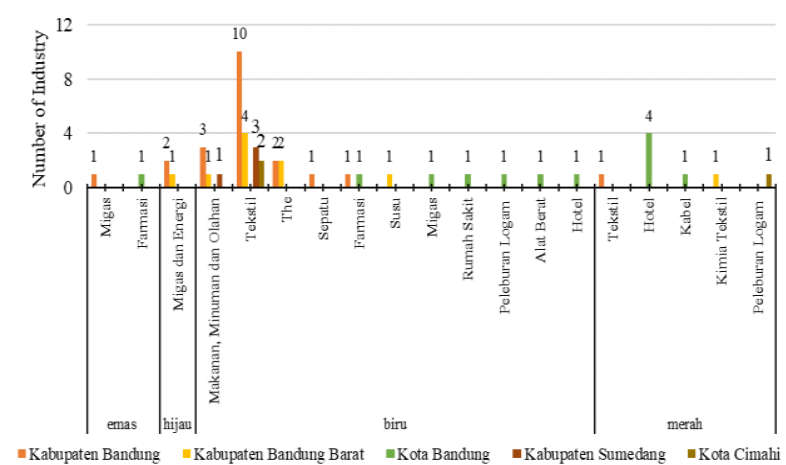

Figure 3 Type Industry Based on Value PROPER in Citarum Hulu

Blue-ranked PROPER shows that industries have conducted environmental management assessment and carry out programs as required in the policy and regulations, including wastewater discharge permit and its monitoring plans based on PermenLHK No. 3/2014. However, these control efforts had not yet reached $100 \%$. Several of these industries had not yet been in compliance to effluent standards on PermenLKH No.5/2014 as they should.

\subsection{Wastewater physical-chemical properties of PROPER registered industries in 2015-2016 and Non-PROPER industries}

\subsection{1pH}

$\mathrm{pH}$ value measures hydrogen ions, indicating the acidity or alkalinity scale of a solution. Figure 4 shows to meet the standard, $\mathrm{pH}$ must be within the range of 6-9, according to PermenLKH No.5/2014. Alkaline or acid water may be harmful to living organism due to its interference to metabolism and respiration system. Ideal $\mathrm{pH}$ for aquatic organisms varies between 7 to 8.5 .
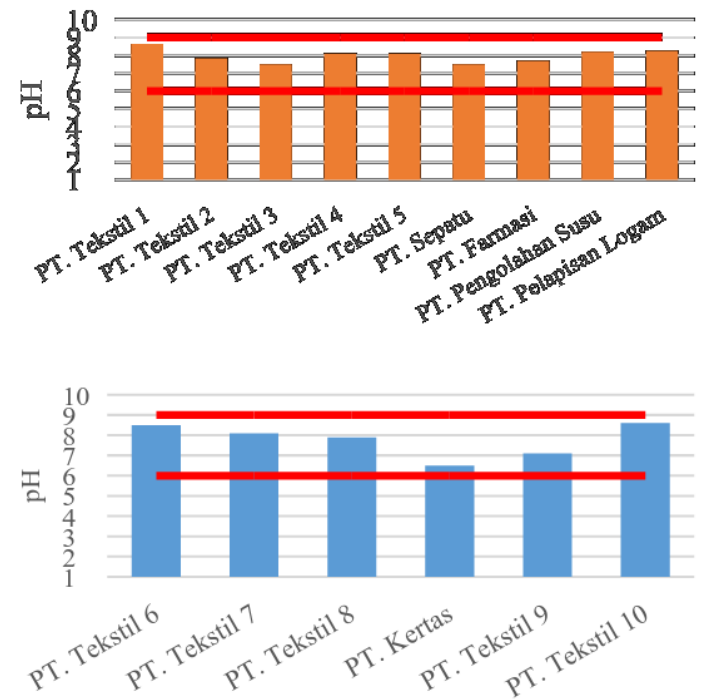

Figure 4 Concentration of $\mathrm{pH}$ wastewater effluent. Above: industry participants PROPER 2015 - 2016 and below: industrial non PROPER

\subsubsection{Conductivity/Electric conductivity (EC)}

Conductivity measures strength of a solution to pass electrical flow through conductive ion contents. PT. Pelapisan Logam (PT. Metal Coating) had the highest conductivity reaching $3950 \mu \mathrm{s} / \mathrm{cm}$, while PT. Tekstil 4 had the smallest conductivity, which is $389 \mu \mathrm{s} / \mathrm{cm}$ for PROPER industries. Non-PROPER industries have higher value with the highest reached $4030 \mu \mathrm{s} / \mathrm{cm}$ (PT. Tekstil 8) and the lowest value of $645 \mu \mathrm{s} / \mathrm{cm}$ (PT. Tekstil 10). Full result is shown in Figure 5. High value of conductivity in wastewater effluent means ther is rich mineral content. Conductivity value depends on content of inorganic ions (Tchobanoglous, 2003). 

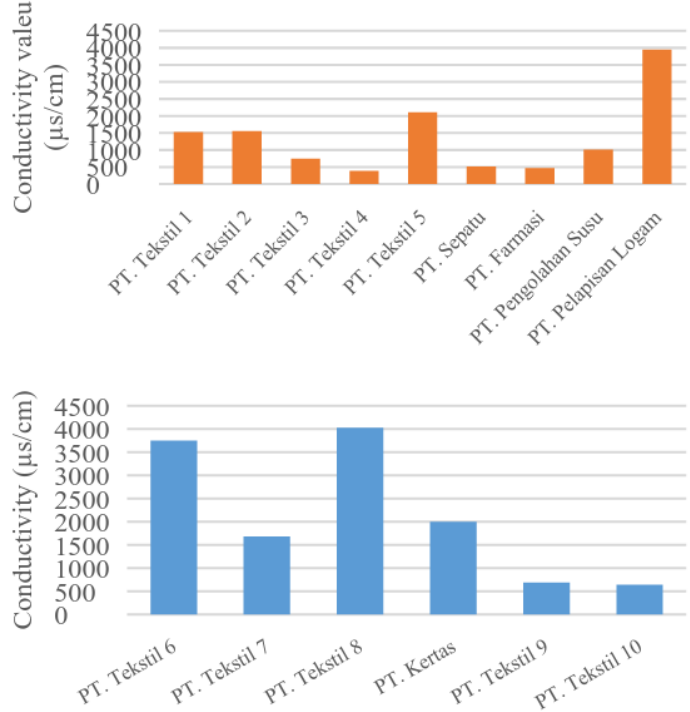

Figure 5 Concentration of Conductivity wastewater effluent. ABove: industry participants PROPER 2015 - 2016 and below: industrial non PROPER

\subsubsection{Turbidity}

Turbidity shows inorganic or organic material content in a solution or water. This inorganic or organic material can affect the ecosystem of aquatic organism. Figure 6 shows PROPER industries have the greatest value of turbidity of 135 NTU (PT. Tekstil 1), while the lowest is 19.133 NTU (PT. Tekstil 3). Non-PROPER industries have higher range on turbidity value, reaching 331 NTU (PT. Paper) as the highest and 52.2 NTU (PT. Tekstil 8) for the least turbid. Turbidity indicates fine particle contents suspended in a solution or wastewater and causing light not able to propagate straight into solutions. High value of turbidity indicates greater level of pollution in bodies of water.
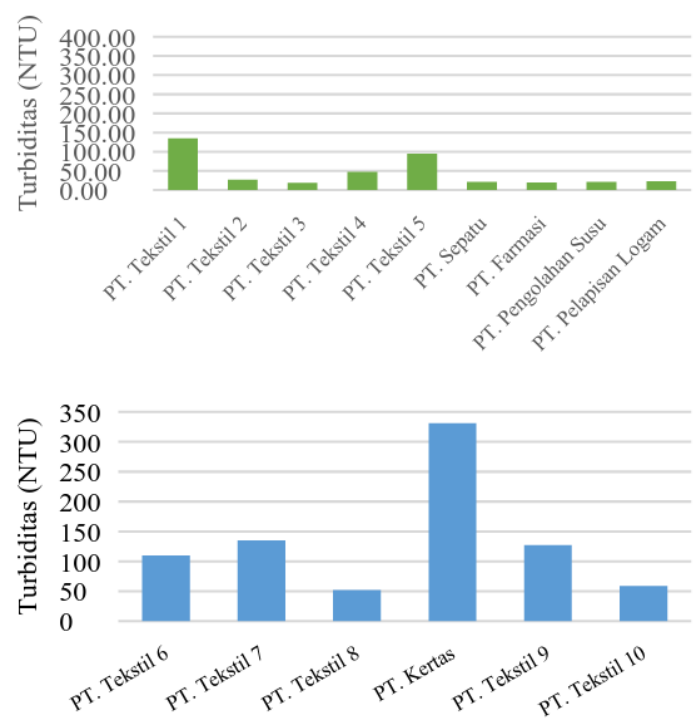

Figure 6 Concentration of Turbidity in wastewater effluent. Above: PROPER industries 2015 - 2016 and below: nonPROPER industries

\subsubsection{Total Suspended Solids/TSS}

TSS is residual total solids with maximum particle size of $2 \mu \mathrm{m}$ or larger than the size of the colloidal particles. Figure 7 shows TSS in wastewater from PROPER and non-PROPER industries in 2015-2016. Lower range was found in PROPER industries, as $456 \mathrm{mg} / \mathrm{L}$ (PT. Tekstil 5) for the most TSS content and $86 \mathrm{mg} / \mathrm{L}$ (PT. Tekstil 2) for the least, and higher range was from non-PROPER industries with $592 \mathrm{mg} / \mathrm{L}$ (PT. Kertas) as the highest and $224 \mathrm{mg} / \mathrm{L}$ (PT. Tekstil 10) as the lowest. TSS content will reduce sun penetration into the water, affecting oxygen regeneration from photosynthesis and may cause disruption to aquatic organism growth.
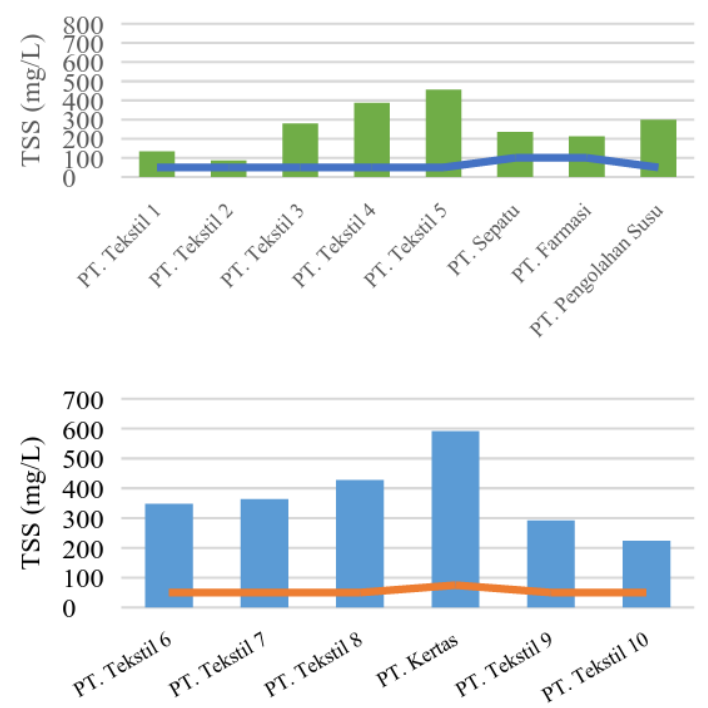

Figure 7 Concentration of TSS wastewater effluent. Above: PROPER industries 2015 - 2016 and below: non-PROPER industries

\subsubsection{Total Dissolved Solis/TDS}

TDS indicates dissolved content, whether organic or inorganic substances in liquid solution. Figure 8 shows TDS value in PROPER industries in 2015-2016and nonPROPER industries. For PROPER industries in 2015 2016, the highest value was $3480 \mathrm{mg} / \mathrm{L}$ (PT. Metal Coating) and the smallest value was $144 \mathrm{mg} / \mathrm{L}$ (PT. Pharmacy). As for non-PROPER industry, the highest value was $3004 \mathrm{mg} / \mathrm{L}$ (PT. Textile 6) and the lowest was $640 \mathrm{mg} / \mathrm{L}$ (PT. Textile 10). TDS value measures inorganic materials in ion. Conductivity correlates with TDS due to the concentration of ionized dissolved solids in water. 

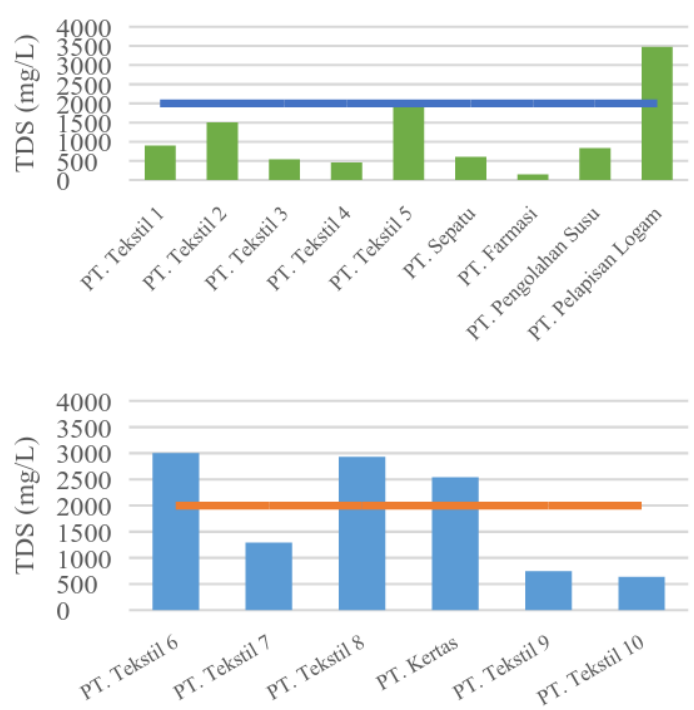

Figure 8 Concentration of TDS wastewater effluent. Above: PROPER industries 2015 - 2016 and below: non-PROPER industries

\subsubsection{Chemical Oxygen Demand (COD)}

COD represents the amount of oxygen required to oxidize organic substances contained in water (Boyd, 1990). Figure 9 shows COD value of PROPER industries in 2015-2016 and non-PROPER industries. All PROPER industries in 2015-2016 discharged wastewater with COD content meeting the standards in PermenLKH No. 5/2014, with the highest value of 198.4 (PT. Tekstil 1) and $121.6 \mathrm{mg} / \mathrm{L}$ (PT. Tekstil 2) as the lowest. Non-PROPER industries show relatively higher COD with wider range from $320 \mathrm{mg} / \mathrm{L}$ (PT. Tekstil 10) to $3840 \mathrm{mg} / \mathrm{L}$ (PT. Tekstil 9). Greater amount of COD in wastewater causes DO to decrease, leading to death for test animals (Effendi, 2003).
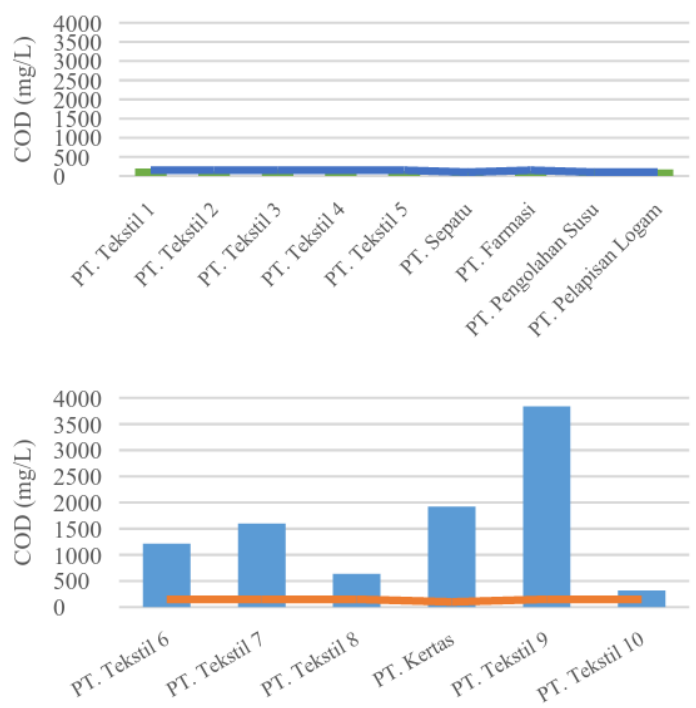

Figure 9 Concentration of COD wastewater effluent. Above: industry participants PROPER 2015 - 2016 and below: industrial non PROPER

\subsubsection{Total Hardness}

Total hardness of PROPER industries of 2015-2016 and non-PROPER industries (Figure 10), which is the amount of $\mathrm{Ca}^{2+}$ and $\mathrm{Mg}^{2+}$ ions, was determined by EDTA titration and used cation-sensitive indicators. PROPER industries had the range of $9.34 \mathrm{mg} / \mathrm{L} \mathrm{CaCO}_{3}$ (PT. Pharmacy) to $214.21 \mathrm{mg} / \mathrm{L} \mathrm{CaCO}_{3}$ (PT. Textiles 1), as for non-PROPER industries from $20.31 \mathrm{mg} / \mathrm{L} \mathrm{CaCO}_{3}$ (PT. Tekstil 10) to $253.81 \mathrm{mg} / \mathrm{L} \mathrm{CaCO} 3$ (PT. Textile 6). Based on the toxicity level, greater hardness of water may limit fish growth while low hardness can increase fish sensitivity to toxic metals.
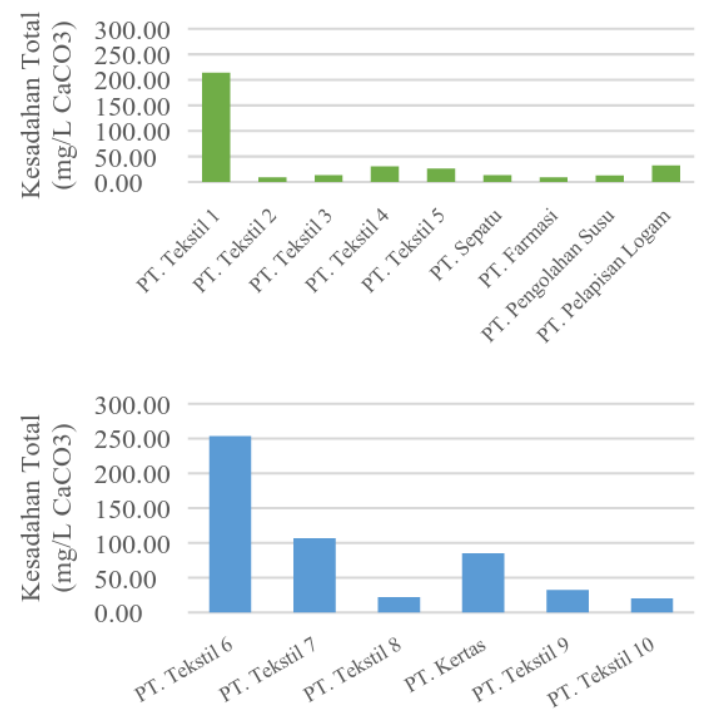

Figure 10 Concentration of Total Hardness wastewater effluent. Above: PROPER industries 2015 - 2016 and below: non-PROPER industries

\subsubsection{Total Alkalinity}

The alkalinity is the ability of wastewater to neutralize acid or anion quantity, which neutralizes hydrogen cations. Figure 11 shows that PROPER industries have relatively lower content of total alkalinity compared to non-PROPER industries, ranging from $35 \mathrm{mg} / \mathrm{L} \mathrm{CaCO}_{3}$ (PT. Metal Coating) to $970 \mathrm{mg} / \mathrm{L} \mathrm{CaCO}_{3}$ (PT. Textile 5). Non-PROPER industries had relatively higher value rangeing from $1200 \mathrm{mg} / \mathrm{L} \mathrm{CaCO}_{3}$ to $3,700 \mathrm{mg} / \mathrm{L} \mathrm{CaCO}_{3}$ (PT. Tekstil 6) and the lowest value of $1,200 \mathrm{mg} / \mathrm{L}$ $\mathrm{CaCO}_{3}$. Optimum alkalinity ranges from 90 to $150 \mathrm{mg} / \mathrm{L}$ $\mathrm{CaCO}_{3}$, while lower alkalinity is limited to the value of 5 $\mathrm{mg} / \mathrm{L} \mathrm{CaCO}_{3}$. Aquatic organisms tend to avoid high water with alkalinity, which is also proportional to hardness. 


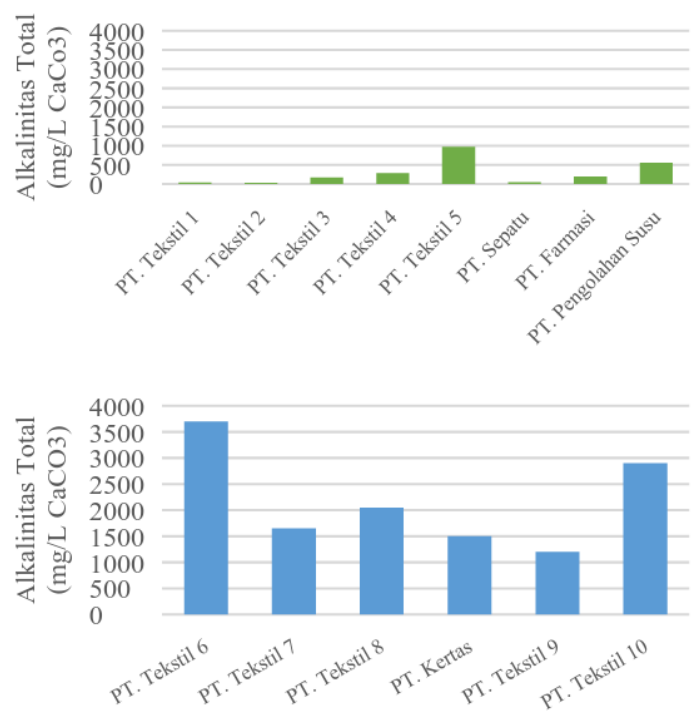

Figure 11 Concentration of Total Alkalinity wastewater effluent. Above: PROPER industries 2015 - 2016 and below: non-PROPER industries

\subsubsection{Ammonium}

Figure 12 shows total ammonium in PROPER industries of 2015-2016 and non-PROPER industries, with the highest content reaching $4.06 \mathrm{mg} / \mathrm{L}$ (PT. Textiles 1) for PROPER industries of 2015-2016 and $13.64 \mathrm{mg} / \mathrm{L}$ (PT. Textile 10) for non-PROPER industries. Lowest value was reaching $1.73 \mathrm{mg} / \mathrm{L}$ (PT. Textile 6) for PROPER industries and $4.35 \mathrm{mg} / \mathrm{L}$ for non-PROPER. At low concentration, high ammonium content may lead to lower rate of physical development and, accumulatively, death in fish and shrimp (Da Cruz, 2007).
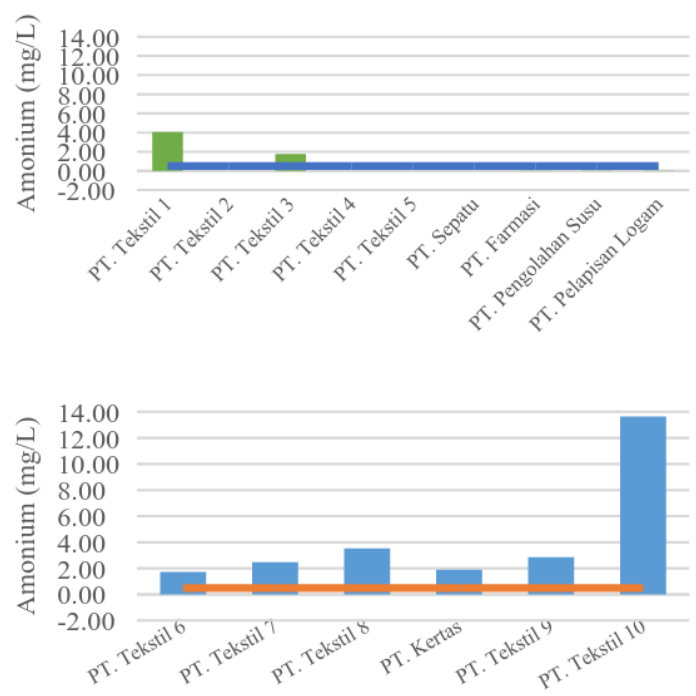

Figure 12 Concentration of Ammonium wastewater effluent. Above: PROPER industries 2015 - 2016 and below: nonPROPER industries

\subsubsection{Total Phosphate}

Phosphate is major source of potassium and nitrogen that are not soluble in water. Figure 13 shows that PROPER industries of 2015-2016 with the most total phosphate content was reaching $1.25 \mathrm{mg} / \mathrm{L}$ (PT. Tekstil 4), while non-PROPER ranged from $2.03 \mathrm{mg} / \mathrm{L}$ (PT. Textiles 9 \& PT. Paper) to $0.21 \mathrm{mg} / \mathrm{L}$ (PT. Textile 8 ).
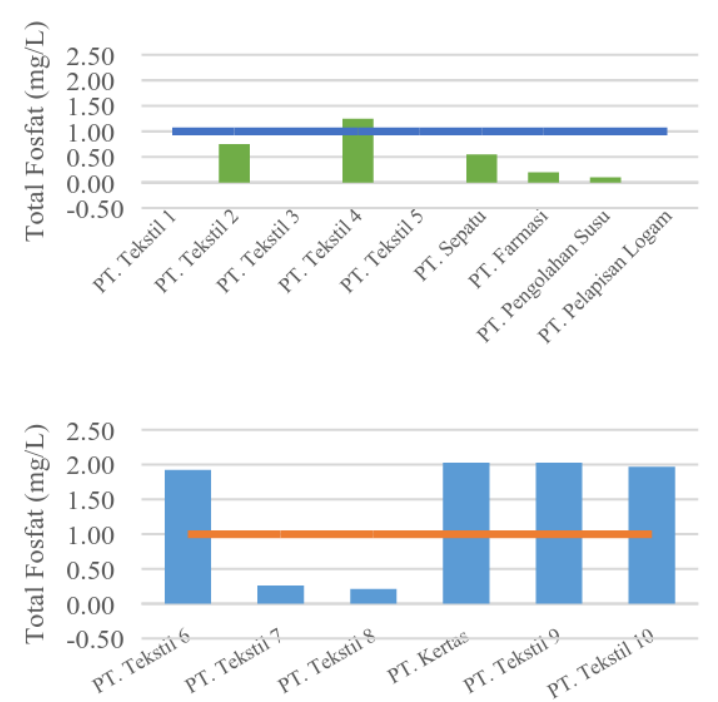

Figure 13 Concentration of Total Phosphate wastewater effluent. Left: PROPER industries 2015 - 2016 and right: nonPROPER industries

\subsection{Whole Effluent Toxicity Test: Reference test} During reference test, Daphnia magna was exposed with $\mathrm{NaCl}$ for 24 hours as control reference. Concentration varied between $5 \mathrm{~g} / \mathrm{L}, 4.8 \mathrm{~g} / \mathrm{L}, 4.6 \mathrm{~g} / \mathrm{L}, 4.4 \mathrm{~g} / \mathrm{L}$ and 4.2 $\mathrm{g} / \mathrm{L}$. Reference test results showed $50 \%$ death of Daphnia magna, shown in Table 3.

Table 3 LC50 Value of The Reference Test

\begin{tabular}{|c|c|c|c|c|}
\hline No. & $\begin{array}{c}\text { Date of } \\
\text { Reference Test }\end{array}$ & $\begin{array}{c}\text { LC50 } \\
\text { Value }\end{array}$ & Average & $\begin{array}{c}\text { Deviation } \\
\text { Standard }\end{array}$ \\
\hline 1 & 12 June 2016 & 4,903 & \multirow{2}{*}{4,685} & \multirow{2}{*}{0,584} \\
\hline 2 & 16 July 2016 & 5,128 & \multirow{2}{*}{4 16 } & \\
\hline 3 & 16 August 2016 & 4,023 & & \\
\hline
\end{tabular}

Results shows that average LC50 from three reference tests is 4.685 , which is close to the value mentioned in literatures, therefore it is adequate to do the WET test.

\subsection{Range Finding Test}

Results of range finding test (Table 4 and Table 5) shows the average $\mathrm{LC}_{50}$ value from nine industry is $37.50 \%$ with the lowest score of $8.652 \%$ and the highest of $100 \%$. Values closer to $100 \%$ indicates more toxic wastewater. This narrows down new combination of concentration in the definitive test. 
Table 4 LC50-48 Hours Test Range Finding for Industry Participants PROPER 2015 - 2016

\begin{tabular}{|c|c|c|c|}
\hline No. & Name of Industry & $\begin{array}{c}\text { LC50 } \\
\mathbf{9 6} \text { hour } \\
(\mathbf{\%})\end{array}$ & Range (\%) \\
\hline 1 & PT. Textile 1 & 12,023 & $6,25-12,5$ \\
\hline 2 & PT. Textile 2 & 22,054 & $12,5-25$ \\
\hline 3 & PT. Metal Coating & 46,72 & $25-50$ \\
\hline 4 & PT. Pharmacy & 19,347 & $12,5-25$ \\
\hline 5 & PT. Textile 3 & 10,854 & $6,25-12,5$ \\
\hline 6 & PT. Textile 4 & 100,916 & $50-110$ \\
\hline 7 & PT. Milk Processing & 56,691 & $50-100$ \\
\hline 8 & PT. Shoe & 60,222 & $50-100$ \\
\hline 9 & PT. Textile 5 & 8,652 & $6,25-12,5$ \\
\hline
\end{tabular}

Table 5 LC50-48 Hours Test Range Finding. For Industrial Non PROPER

\begin{tabular}{|c|c|c|c|}
\hline No. & $\begin{array}{c}\text { Name of } \\
\text { Industry }\end{array}$ & $\begin{array}{c}\text { LC50 96 } \\
\text { hour (\%) }\end{array}$ & $\begin{array}{c}\text { Range } \\
\mathbf{( \% )}\end{array}$ \\
\hline 1 & PT. Textile 6 & 24,152 & $12,5-25$ \\
\hline 2 & PT. Textile 7 & 34,351 & $25-50$ \\
\hline 3 & PT. Textile 8 & 20,987 & $12,5-25$ \\
\hline 4 & PT. Paper & $35 \times 10^{9}$ & \\
\hline 5 & PT. Textile 9 & 43,908 & $25-50$ \\
\hline 6 & PT. Textile $10_{*}$ & 0 & \\
\hline
\end{tabular}

\subsection{Definitive Test}

Definitive test results were analyzed using probit software. $\mathrm{LC}_{50-96}$ was obtained from software analysis, then reviewed to find whether there was any link between the value LC50-96 hours with PROPER value criteria. Variations of concentration in this test were obtained from result range on the range finding test, obtained by multiplying $\mathrm{R}$ value in Equation 1 with initial value range. Table 6 and Table 7 shows $\mathrm{LC}_{50-96}$ value in definitive test.

Table 6 Value LC50-96 Hour Definitive test results. For Industry Participants PROPER 2015 - 2016

\begin{tabular}{|c|c|c|c|}
\hline Name of Industry & $\begin{array}{c}\text { LC50 96 hour } \\
\text { Definitif Test } \\
(\%)\end{array}$ & TUa & $\begin{array}{c}\text { PROPER } \\
\text { Value }\end{array}$ \\
\hline PT. Tekstil 1 & 6,357 & 15,73 & Biru \\
\hline PT. Tekstil 2 & 13,555 & 7,377 & Biru \\
\hline PT. Pelapisan Logam & 20,567 & 4,862 & Merah \\
\hline PT. Farmasi & 12,967 & 7,712 & Biru* \\
\hline PT. Tekstil 3 & 2,719 & 36,78 & Biru \\
\hline PT. Tekstil 4 & 88,399 & 1,131 & Biru \\
\hline PT. Pengolahan Susu & 45,097 & 2,217 & Merah* \\
\hline PT. Sepatu & 49,959 & 2,002 & Biru \\
\hline PT. Tekstil 5 & 7,585 & 13,18 & Biru \\
\hline
\end{tabular}

Table 7 Value LC50-96 Hour Definitive test results for Industry Non PROPER

\begin{tabular}{|c|c|c|}
\hline $\begin{array}{c}\text { Name of } \\
\text { Industry }\end{array}$ & $\begin{array}{c}\text { LC50 96 hour } \\
\text { Definitif Test } \\
\text { (\%) }\end{array}$ & TUa \\
\hline PT. Tekstil 6 & 17,25 & 5,80 \\
\hline PT. Tekstil 7 & 9,96 & 10,04 \\
\hline PT. Tekstil 8 & 9,05 & 11,05 \\
\hline PT. Tekstil 9 & 9,31 & 10,74 \\
\hline
\end{tabular}

According to Maryland Department of the Environment (2012), WET data interprets toxic in samples when generating $\mathrm{LC}_{50}$ or $\mathrm{EC}_{50}$ value less than or equal to $100 \%$ effluent concentration. Table 5 shows that $\mathrm{LC}_{50-96}$ value of all samples from industry wastewater effluent was less than $100 \%$, indicating they are not fit to be discharged.

\subsection{Environment Parameter}

USEPA (2002) recommends to conduct environmental parameter measurement for $\mathrm{pH}$, temperature, DO and conductivity. These assessment is intended to monitor abrupt environmental changes due to toxicity. The toxicity in this test is measured by using Daphnia Magna.

\subsubsection{Dissolved oxygen (DO)}

Daphnia sp. lives in condition with DO content above 3 $\mathrm{mg} / \mathrm{l}$ (Ebert, 2005). DO is required for metabolism. Figure 14 shows average value of DO in samples from both PROPER industries of 2015-2016 (ranges between 5.0-7.0) and non-PROPER industries (between 6.0-8.0) are in the optimum range for Daphnia to survive.
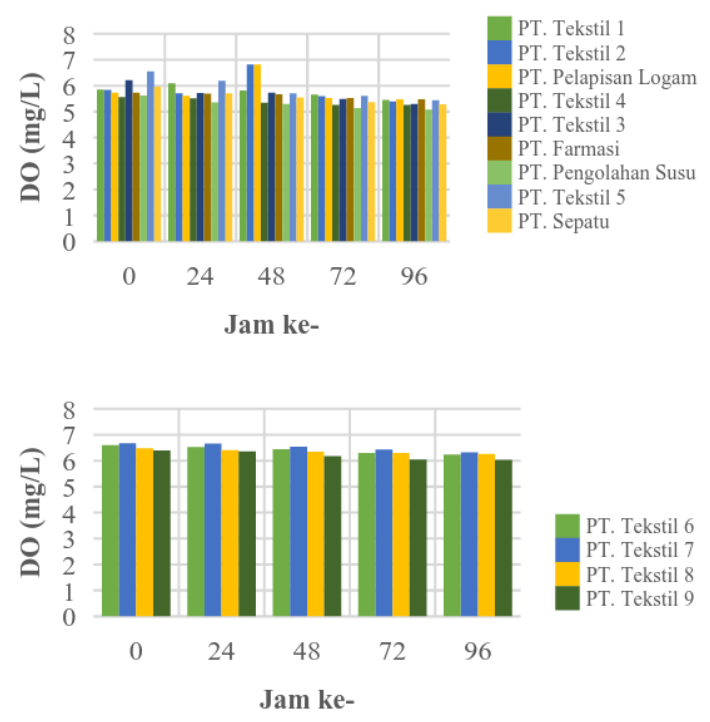

Figure 14 Measurement Parameters DO during test Definitive. Above: PROPER industries 2015 - 2016 and below: nonPROPER industries 


\subsubsection{Temperature}

Optimum temperature ranges from $20-30^{\circ} \mathrm{C}$ for phytoplankton growth in water environment (Effendi, 2003). Temperature affects organism survival ability, for example algae grows well in the temperature range of $30-35^{\circ} \mathrm{C}$ and $20-30^{\circ} \mathrm{C}$. Room temperature is a right condition for organism to metabolize and reproduce.
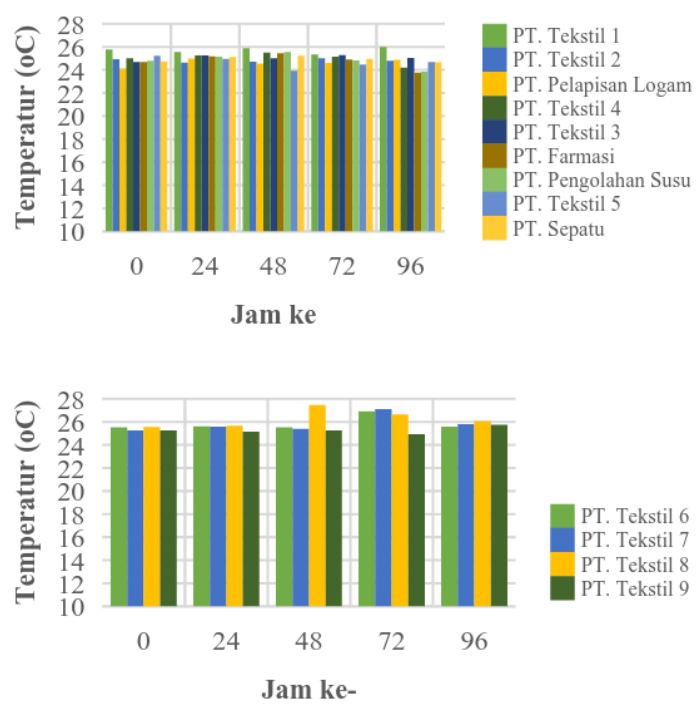

Figure 15 Measurement Parameters Temperature during Test Definitively. Above: PROPER industries 2015 - 2016 and below: non-PROPER industries

Figure 15 shows different range among PROPER industries of 2015-2016 (24-26 $\left.{ }^{\circ} \mathrm{C}\right)$ and non-PROPER industries $\left(24-27{ }^{\circ} \mathrm{C}\right)$, however, both are still among optimum temperature range for Daphnia $s p$. to live. Condition with temperature out of the optimum range will disrupt its growth and development.

\subsubsection{Conductivity/Electrical Conductivity (EC)}

Conductivity, which is influenced by free ion content such as heavy metal ions released by pollutants in wastewater (Fonridest Environmental, 2014), shown in Figure 16 indicates PT. Metal Coating had the highest EC value amongst all PROPER industries measurements for 48 hour $(1000-2200 \mu \mathrm{s} / \mathrm{cm})$. PT. Tekstil 8 excelled amongst all non-PROPER industries $(700-900 \mu \mathrm{s} / \mathrm{cm})$.
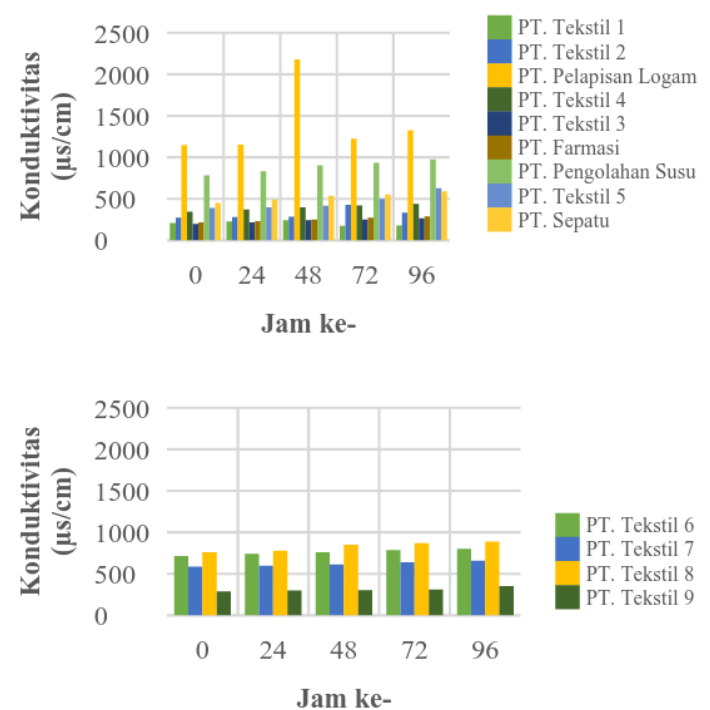

Figure 16 Measurement parameters Conductivity during Definitive Test. Above: PROPER industries 2015 - 2016 and below: non-PROPER industries

\section{$3.6 .4 \mathrm{pH}$}

According to Pennak (1989), optimum $\mathrm{pH}$ growth for of Daphnia sp. ranges from 6.5 to 8.5. Figure 17 shows PT. Milk Processing as the highest $\mathrm{pH}$ (in the range of 8.90-9.20) amongst other PROPER industries, which were in the range of 8.0 to 8.7 . For non-PROPER industries $\mathrm{pH}$ were in the range be 7.5 - 8.5. Both PROPER and non-PROPER industries had $\mathrm{pH}$ value in the optimum growth range for Daphnia sp., except for PT. Milk Processing and PT. Tekstil. pH value above or below the optimum range growth may cause death (USEPA, 2002).
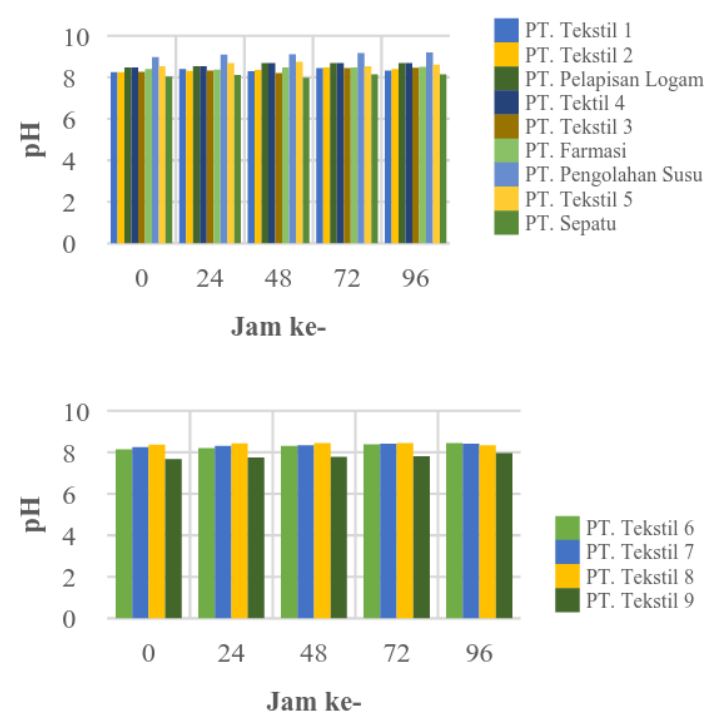

Figure 17 Measurement parameters $\mathrm{pH}$ during Definitive Test, Above: PROPER industries 2015 - 2016 and below: nonPROPER industries 


\subsection{Evaluation of PROPER 2015 - 2016 Criteria Based Value Acute Toxicity and Industrial Wastewater Physical-Chemical Characteristics}

The smaller $\mathrm{LC}_{50}$ value points out more toxic properties in the wastewater. Figure 18 shows acute toxicity proportion for blue-category PROPER, indicating $\mathrm{LC}_{50}$ 96 value below $100 \%$. PT. Tekstil 3 had the least $\mathrm{LC}_{50}$ value reaching $2.719 \%$, which had not met reference standard of $\mathrm{LC}_{50-96}$ value based on Maryland Department of the Environment (2012). Based on this result, bluecategory PROPER received by industries would not indicate low toxicity level, because toxicity test standards have not been included into indicator of environmental assessments.
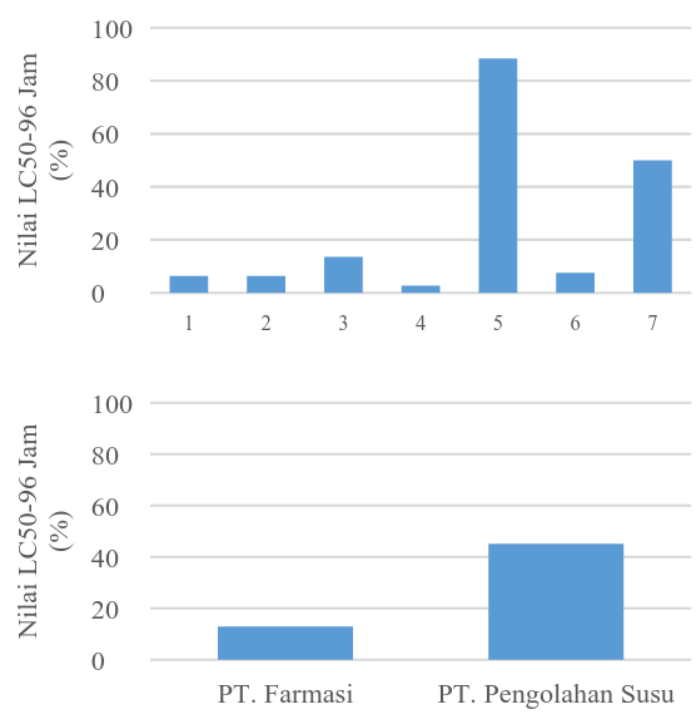

Figure 18 Value Acute Toxicity Criteria LC50-96 hours against PROPER. Left: Industry Participants PROPER and Right: New Participants PROPER Industry 2015 - 2016

Both graphics on Figure 18 contains information on all 9 PROPER industries of 2015-2016 with 2 new industries registered as PROPER industries in 2016 based on their current report, namely PT. Farmasi (bluecatogory PROPER) and PT. Pengolahan Susu (redcategory PROPER). Figure 18 shows lower $\mathrm{LC}_{50-96}$ value for PT. Farmasi than PT. Pengolahan Susu. Better ranking, such as blue-category PROPER, did not indicate lower toxicity in the wastewater. Different raw material from both industries may be a contributing factor to this condition, considering chemicals is mostly used for PT. Farmasi.

Figure 18 also shows both blue and red category of PROPER have $\mathrm{LC}_{50-96}$ value less than $100 \%$, pointing out toxicity level of the discharged wastewater. This result draws one example of blue-category PROPER, that have implemented environmental assessment and management as regulated in PermenLHK No. 3/2014, contrarily discharged toxic wastewater. The figure is also drawing red-category PROPER example that also discharged toxic wastewater, despite the undergoing efforts in environmental management. Physical and chemical parameters of environmental monitoring standards still did not met the standard in PermenLKH No. 5/2014 even as the toxicity tests are ruled out.

\section{CONCLUSION}

PROPER and non-PROPER industries of 2015-2016 discharged wastewater with some of its parameters exceeding the standard regulated in PermenLKH No. $5 / 2014$. These following physical-chemical parameters in PROPER industries of 2015-2016 wastewater were exceeding the standards regulated in PermenLKH No. $5 / 2014$, namely COD (67\% of the industries), TSS $(100 \%)$, TDS $(22 \%)$, phenol $(78 \%)$, ammonium $(22 \%)$ and phosphate $(11 \%)$. Several non-PROPER industries of 2015-2016 had parameters exceeding standard as well, namely COD $(100 \%$ of the industries), TSS $(100 \%)$, ammonium $(100 \%)$, phosphate $(67 \%)$ and TDS $(50 \%)$.

$\mathrm{LC}_{50-96}$ value results from Whole Effluent Toxicity (WET) tests shows 100\% wastewater from all industries are toxic. PT. Tekstil 3 and PT. Tekstil 8 were the most toxic wastewater with TUa value of 36.78 and 11.05 .

Blue-category PROPER industries, which are $78 \%$ of all PROPER industries of 2015-2016, still discharged toxic wastewater. Higher rank on PROPER categories did not indicate low toxicity of wastewater.

Several PROPER-registered industries discharged wastewater with parameters exceeding the standard, as regulated in PermenLKH No. 3/2014.

\section{REFERENCES}

1. Davraz, Metin., Koru, Murat., and Akdag, Ali Ekrem. The Effect of Physical Properties on Thermal Conductivity of Lightweight Aggregate. Procedia Earth and Planetary Science, Suleyman Demirel University, Turkey 15, 85 - 92 (2015)

2. Ebert, D. Ecology. Epidemiology and Evaluation of Parasitism in Daphnia. National Liblary of Medicine (US)-National Center for Biotechnology Information, Bethesda. (2005)

3. Effendi, H. Telaah Kualitas Air Bagi Pengelolaan Sumberdaya dan Lingkungan Perairan. Kanisius. Yogyakarta. 258 p (2003)

4. Habibi, B.J. Peraturan Pemerintah Republik Indonesia Nomor 18 Tahun 1999 Tentang Pengelolaa Limbah Berbahaya dan Beracun. Jakarta (1999)

5. Kambuaya, Balthasar. Peraturan Menteri Lingkungan Hidup Republik Indonesia Nomor 3 Tahun 2014 Tentang Program Penilaian Peringkat Kinerja Perusahaan dalam Pengelolaan Lingkungan Hidup. Jakarta (2014)

6. KLHK. Hasil Evaluasi Kinerja Pengelolaan Lingkungan Proper 2015 - 2016 Rapor Sementara PT. Sanbe Farma. Jakarta (2016)

7. Mark, U dan John Solbe. Analysis of the Ecotoc Aquatic Toxicity (EAT) Database V-the Relevance of Daphnia magna as a Representative Test Species. Chemosphere, 36, 1, pp. 155 - 156 (1997)

8. Mokoginta, I. Budidaya Pakan Alami Air Tawar. 
Direktorat Pendidikan Menengah Kejuruan Direktorat Jendral Pendidikan Dasar dan Menengah Departemen Pendidikan Nasional. Jakarta. 2003.

9. Mount, D.R., Gulley, D.D., Hocket, J.R., Garrison, T.D., Evans, J.M. Statistical Models to Predict The Toxicity of Major Ions to CerioDaphnia dubia, Daphnia magna and Pomephales promelas (Fatted Minnows). Environmental Toxicology and Chemistry, 16 (1997).

10. Ningrum, Sri Rahayu Widiya. Validasi Uji Toksisitas Akut Metode Organization for Economic Cooperation and Development (OECD) 425 pada Mencit Betina Menggunakan Tembaga (III) Sulfat Pentahidrat. Universitas Indonesia. Depok (2012)

11. Pennak, R.W. Freshwater Invertebrate of The United States $\left(3^{\text {rd }}\right.$ ed). John Wiley \& Sons. New York (1989)

12. Pratiwi. A. D. Syah., Hardjito., L. Goreti. Fatty Acid Syntetys by Indonesian Marine Diatom. Hayati Journal of Biosciences. 16(4), 151-156 (2009)

13. Salmiyatun. Panduan Pembuangan Limbah Perbekalan Farmasi. Buku Kedoketaran EGC. Jakarta (2003)

14. Tongur, Suheyla. and Yildirim, Rifat. Acute Toxicity Assessment of Antibiotics in Water by Luminiscene Bacteria and Lepidium Sativum. World Multidisciplinary Earth Sciences Symposium, WMESS 2015. Procedia Earth and Planetary Science. Selcuk University, Department of Enviromental Engineering, Konya. 15, 468 473 (2015)

15. Tyagi., Chopra., Durgapal., and Kumar. Evaluation of Daphnia magna as an Indicator of Toxicity and Treatment Efficacy of Municipal Sewage Treatment Plant. Delhi, India. JASEM ISSN 1119-8362, 11, $61-67$ (2007)

16. U.S. Environmental Protection Agency. Methods for Measuring the Acute Toxicity of Effluents and Receiving Waters to Freshwater and Marine Organisms. Final Report. Office of Water, Washington DC. 5th ed. EPA/821/R-02/012 (2002)

17. William PL, Burson JL. The Basic Science of Toxicity. Macmillan Publ. Co, New York, 54 (1995)

18. Wolfe, D., Schorr, M., Hanson, M., Nelson, C.H. and Richards, S.M. Hazard Assessment for a harmaceutical Mixture Detected in The Upper Tennessee River Using Daphnia magna. Global J. Environ. Sci. Manage., Department of Biological and Environmental Sciences, University of Tennessee at Chattanooga, USA. 1 (1), 1 - 14, (2015)

19. Tchobanoglous, G., Burton, Frankin L., dan Stensel, H. David. Wastewater Engineering : Treatment and Reuse (Fourth Edition). RRC : Metcalft and Eddy, Inc (2003)

20. Boyd, C.E.. Water Quality in Ponds For Aquaculture, Alabama Agricultural Experiment Station. Auburn University. Alabama. 482 p, (1990)

21. Costa Da Cruz, R. Nitrification and Oxidation of
Carbon Sources and Nitrogen Removal in Ammonia Rich Effluents. Portugal. Technical University of Lisbon, Instituto Superior Tecnico. (2007)

22. Maryland Department of the Environment (MDE). Guidance: Effluent Biotoxicity Testing Protocol for Industrial and Municipal Effluents. Water Management Administration, Washington Blvd, Baltimore (2012) 